\title{
IMPLEMENTATION OF ENERGY EFFICIENCY MANAGEMENT SYSTEM IN MULTI-STOREY RESIDENTIAL HOUSES IN LITTORAL REGIONS OF LATVIA
}

\author{
Baiba PḶAVIN̦A ${ }^{\mathbf{1}}$, Gita ACTIN̦A ${ }^{2}$ \\ ${ }^{1,2}$ Riga Technical University, 6 Kalnciema Str., Riga, LV-1048, Latvia \\ Corresponding author`s e-mail: baiba.plavina@inbox.lv
}

\begin{abstract}
Based on EU guidelines and national development plans, energy efficient process management has been slowly implemented in Latvian regions in the context of the Directive 2012/27/EU putting forward two binding indicative national energy efficiency goals for Latvia: (1) to achieve $1.5 \%$ of energy savings delivered to final consumers every year, and (2) to renovate $3 \%$ of the state-owned buildings annually. The aim of the paper is to reflect the management system of energy efficient processes in public and residential buildings in Latvian littoral regions of the Baltic Sea, which can be an important factor for achieving the goals of the Directive. The paper presents the results of the research on energy efficient processes in public and residential buildings in Latvian littoral regions of the Baltic Sea in order to determine the existing challenges. Methods applied in the research are data collection, grouping, analysis and comparison, studies of regulatory documents, as well as statistical data collection and analysis. Contribution of the research is the improvement of energy efficient solutions in public and residential buildings in littoral regions of the Baltic Sea by using the estimated energy efficient processes. The results of the research are of international importance and can be applied not only in public and residential buildings in littoral regions of the Baltic Sea but also in other regions with similar climate or energy efficient process management problems in order to improve the selection of criteria of energy efficient solutions and renovation.
\end{abstract}

Keywords: Energy consumption, energy efficiency processes in littoral regions, financial provision, management methods, residential and public buildings.

\section{INTRODUCTION}

Perspective of spatial development (see Fig. 1) provided by "Sustainable Development Strategy of Latvia until 2030" intends unified functional linkages between cities and rural areas (including littoral regions of the Baltic Sea). To pursuit this priority, it is necessary to take into account that only those regions can become competitive that provide attractive and quality living conditions for the inhabitants. It means that the regional municipality is responsible not only for creating an equivalent level of job conditions, but also, no less important, for living conditions.

To reach the national goals set by Directive 2012/27/EU, considerable energy savings are associated with thermal insulation of residential and public buildings, as well as elaboration of the heating and ventilation systems. Not only in littoral 
regions in particular, but also in Latvia in general, the compilation of statistics shows that a lot of energy is wasted because of inefficient heat consumption.

The present research has shown that in different Latvian regions the shortage of specialists and the respective municipal authorities complicates the implementation of energy efficient process management and convenient energy efficient solutions in residential and public buildings, thus impeding the solution of existing problems at a sufficient level.

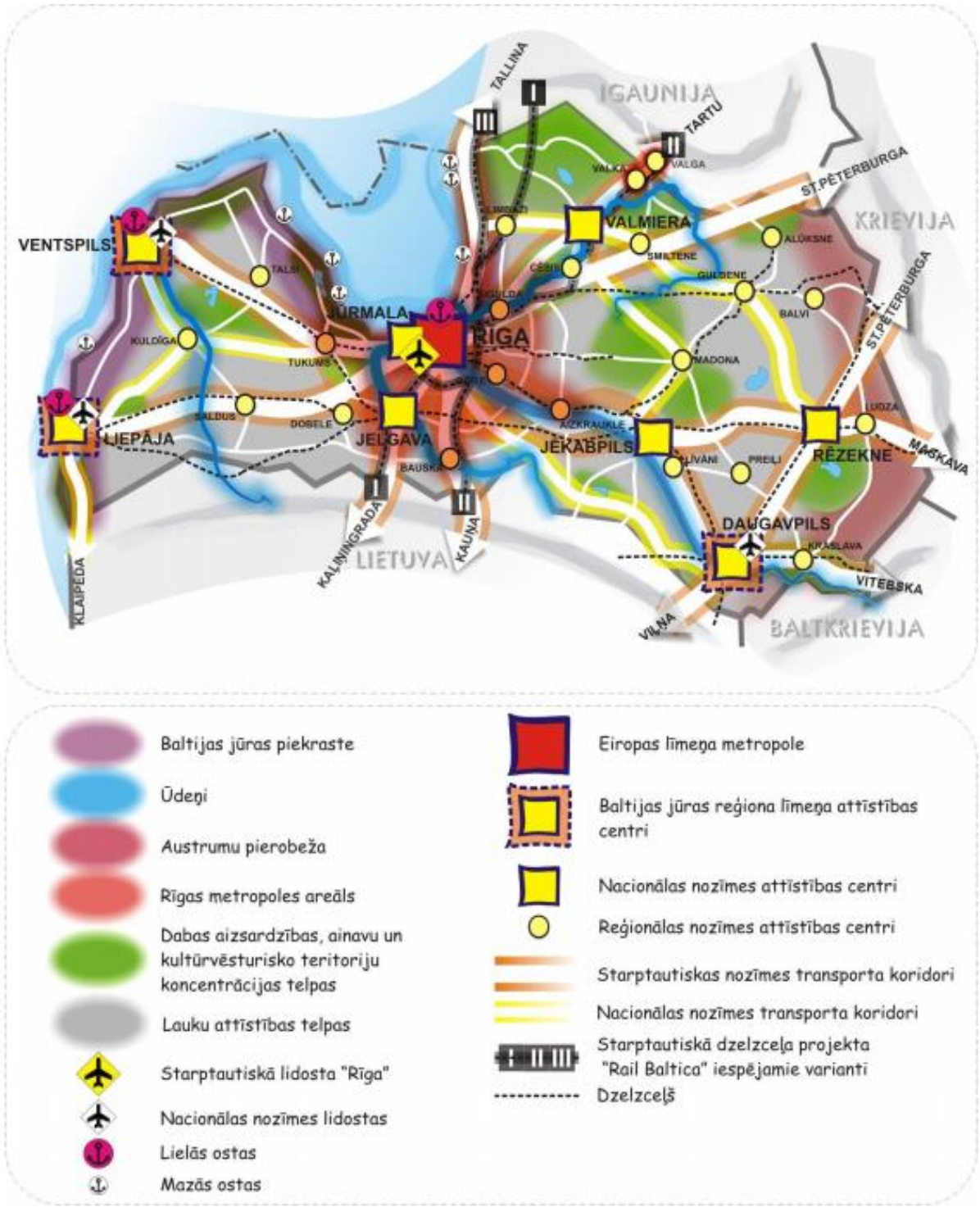

Fig. 1. Future spatial structure of Latvia (Saeima of the Republic of Latvia, 2010).

The legal status of residential buildings after indigested privatization process has also significantly complicated the decision-making and project implementation processes.

The energy efficient process management system is an approach that involves organizational and technical activities, with the task of reducing fuel and energy 
costs of a building, as well as the harmful impact upon the environment in general (Actina, Zeltins \& Geipele, 2014).

The aim of the research is to evaluate the energy efficient processes and to find out the most appropriate energy efficiency solutions for residential and public buildings in littoral regions of Latvia. To reach the aim, the following tasks have been set during the research:

- to demonstrate the urgent need for continuous implementation of energy certification based on the energy audit;

- to reflect the economic justification of the selected energy efficient processes;

- to define the energy efficient process management methods in order to increase energy efficiency by choosing a proper solution.

As the public and residential buildings in littoral regions of Latvia have specific history of legal development, the applicable energy audit and monitoring process can be the best instrument to select optimal energy efficient solutions.

Management of energy efficient processes of multi-storey residential buildings is a complex process. As the building ownership structure depends on the number of apartments in the building, and in general each apartment has a different owner, but the ownership of the common areas of the building is divided proportionally into the total area of the apartment, it is difficult for the apartment owners to select the most effective energy efficient solutions and agree on their implementation (Geipele, Geipele, Slava \& Stāmure, 2012).

Although in littoral regions of the Baltic Sea in Latvia multi-storey residential buildings with a large number of apartment owners are not dominant, different opinions of the owners about the implementation of energy efficient solutions and their financial capacity impede the energy efficient process management. Often, apartment owners are not well informed and aware of the issues related to energy efficient solutions and energy efficient process, as well as of management of joint ownership of houses; therefore, they passively take part in the decision-making process.

To raise the awareness of apartment owners and tenants, it is important to clarify the benefits from the implementation of proper energy efficient solutions:

- increased comfort of the living environment;

- reduced energy consumption;

- economic and environmental benefits.

In order to motivate the owners responsible for energy efficient process management in residential buildings, it is necessary to perform energy audit and monitoring. These activities will determine thermal features of the building and give the assessment of the productivity of energy efficient process management and potential energy savings. The first step towards the determination of energy efficient solutions is the accomplishment of energy audit, which will determine the initial state of the multi-storey residential buildings and provide the initial assessment of possible energy savings. 


\section{STRUCTURE OF INDOOR COMFORT AND ENERGY CONSUMPTION IN RESIDENTIAL AND PUBLIC BUILDINGS}

As it is known, one of the main tasks of the building is to provide a comfortable indoor environment. With the help of energy efficient process management, it is possible to arrange the energy usage in order to retain the comfort level in rooms by operating the heating system - to control the heat losses through the building construction elements, as well as to ensure the operation of the local hot water system, the ventilation system and various household gadgets.

Most residential and public buildings in littoral regions of Latvia are built from clay bricks or reinforced concrete panels. Since most of them were built more than 50 years ago, now they are in bad condition not only because of the aging process but also because of the designing errors and the low-quality construction elements used. The thermal energy losses in these buildings are high and affect the indoor comfort level as well as financial expenses of the inhabitants. Statistics show that the energy usage for heating of residential and public buildings in Latvia is at least two times higher than in Western Europe.

The assessment of energy efficient processes in public and residential buildings in littoral regions will be helpful for apartment owners by choosing the appropriate thermal isolation of the building envelope, improving the heating and ventilation systems in order to achieve a higher comfort level by consuming less energy. It should also be considered that expenses of the implementation of energy efficient solutions can be reduced if the implementation is combined with overhaul and reconstruction of the building.

The comfort balance in public and residential buildings depends on mutual interactions between heat acquisition, which includes heat generation inside a building by internal systems and heat generation by recovery systems, and heat loss through the building construction (Sartori \& Hestnes, 2007). The most important components of the comfort balance are shown in Fig. 2.

Heat acquisition in a building can consist of heat generated inside a building (heating systems, central hot water system, household and lighting equipment etc.) and energy recovery systems, such as solar collectors, heat pumps, air conditioners and ventilation systems (Actina \& Geipele, 2016). Heat losses that can impact the indoor comfort level of the apartment are heat transfer through building constructions (walls, windows, floor, and doors) and heat flow through the air gaps and glass surfaces.

As it has been mentioned above, most public and residential buildings in littoral regions of the Baltic Sea in Latvia still are in critical condition and need to be renovated. Great financial investment caused by large-scale measures of energy efficient solutions is the obstructive factor to their all-embracing implementation. To motivate apartment owners and tenants to implement energy efficient solutions, it is essential to apply innovative management and financial mechanisms appropriate for the littoral regions that should be carried out by local municipalities. 


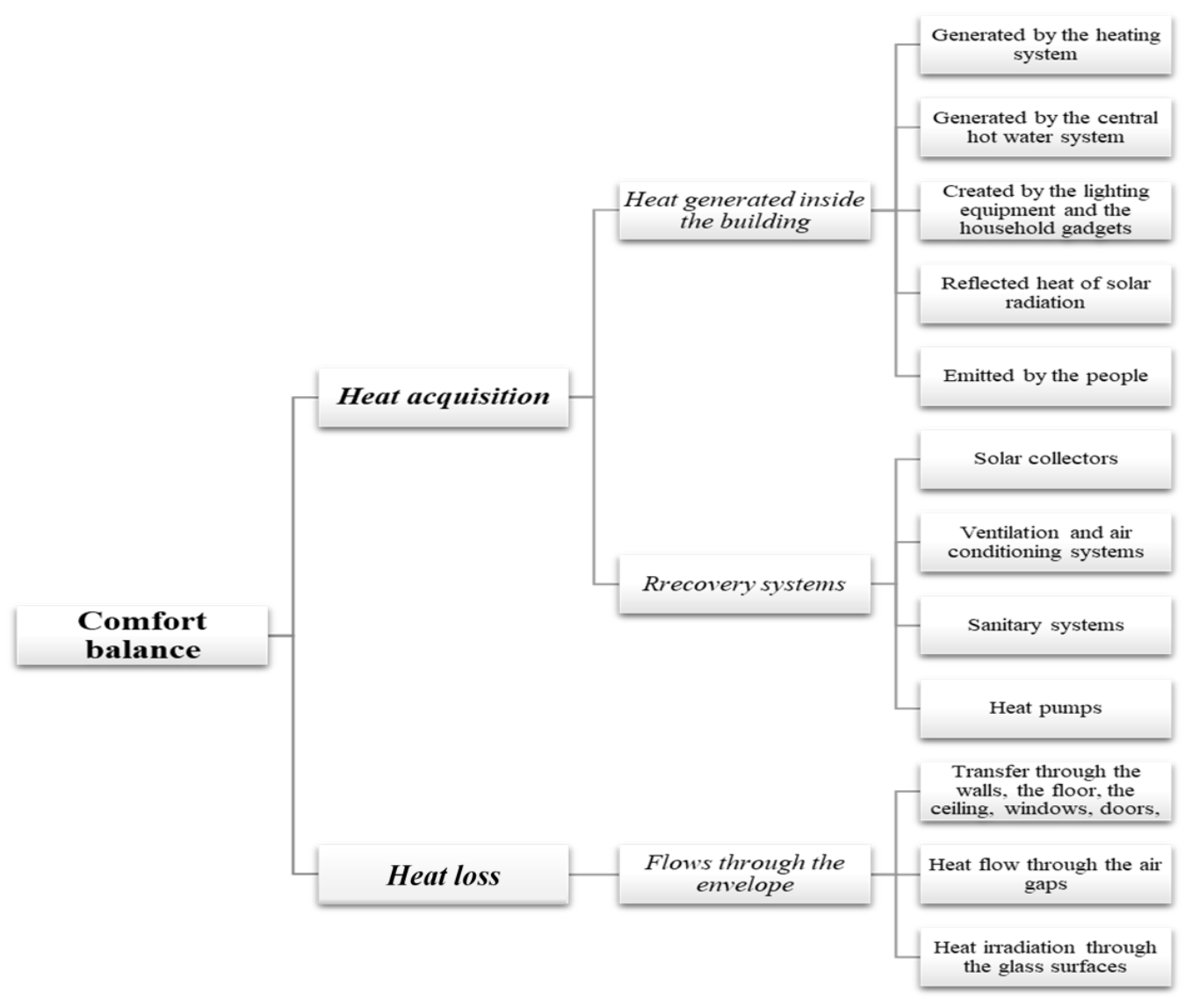

Fig. 2. The energy equilibrium components (Actina \& Geipele, 2016).

\section{ENERGY EFFICIENT PROCESS MANAGEMENT SYSTEM OF PUBLIC AND RESIDENTIAL BUILDINGS IN LITTORAL REGIONS}

The goals set by EU Directive 2012/27/EC are focused on the integration of management systems. Municipalities of littoral regions of the Baltic Sea in Latvia are still working on implementation of the energy efficient process management system and the selection criteria of the financing system. Assessment of energy efficient processes in public and residential buildings will allow the municipality and apartment owners to determinate the thermal characters of a building and the structure of potential energy savings.

Likewise the environmental management system, continual improvement is the main principle and the general guideline of energy efficient process management in public and residential buildings (Pelz, 2012). However, any branch of national economy has its specificity. The choice of the management method for this system relates to the solution of the problems concerning the institutional and financial support. Municipality restricted investment amount imposes significant limitations on the selection of priority energy efficient solutions, which give the greatest effect. 
Determination of the initial state of the building and identification of the energy saving measures is the first step towards proposing energy efficient solutions (Hernandez, Burke \& Lewis, 2008). Beneficial energy efficient process management system in public and residential buildings can be characterized as a series of repetitive activities arranged in a cycle (see Fig. 3).

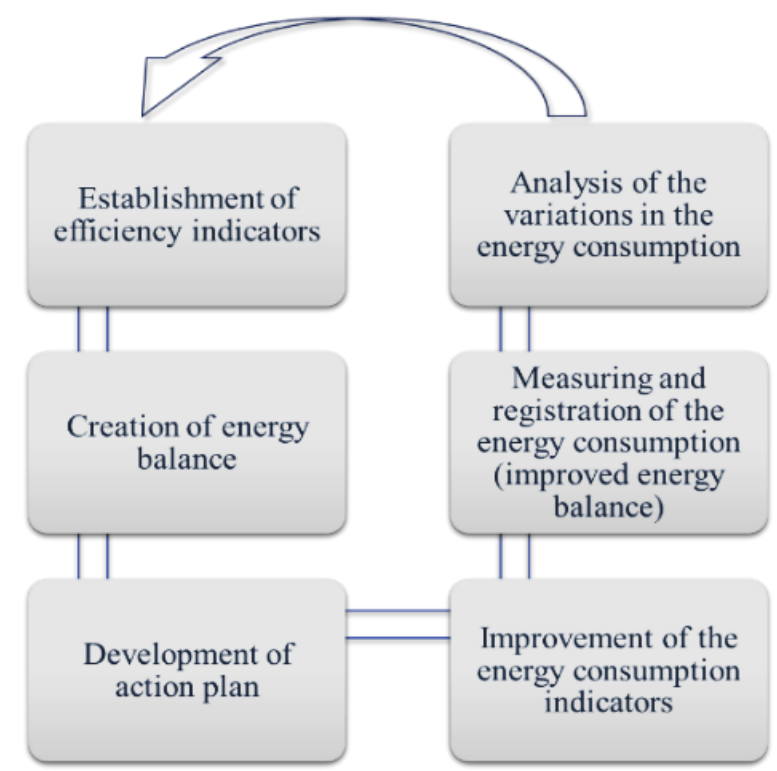

Fig. 3. Energy efficient process management system in public and residential buildings (developed by the authors).

Energy audit of a multi-storey residential building performed by a regional municipality can serve as a substantiation for the motivation of the apartment owners and tenants, based on the conducted concrete data. To obtain accurate thermal characteristics and to determine the potential of energy savings, the responsible building management company should be involved in the energy audit initial data collection process (see Fig. 4). As apartment owners of a multi-storey residential building will eventually be the main project investors and providers of possible credit repayment, the results of the energy audit must be of distinctive importance.

Based on the calculation of heat consumption of a building, the energy audit states thermal losses through various components of the envelope of a building (the walls, windows, the roof, etc.) before and after thermal insulation (Akermanis, Zebergs, Zeltins, Actina, \& Odineca, 2012), thus showing the potential of economy of thermal energy and finances. Using the obtained calculations, it is possible to develop an energy efficient process management plan in a qualitative way and choose a further renovation activity of the building. 


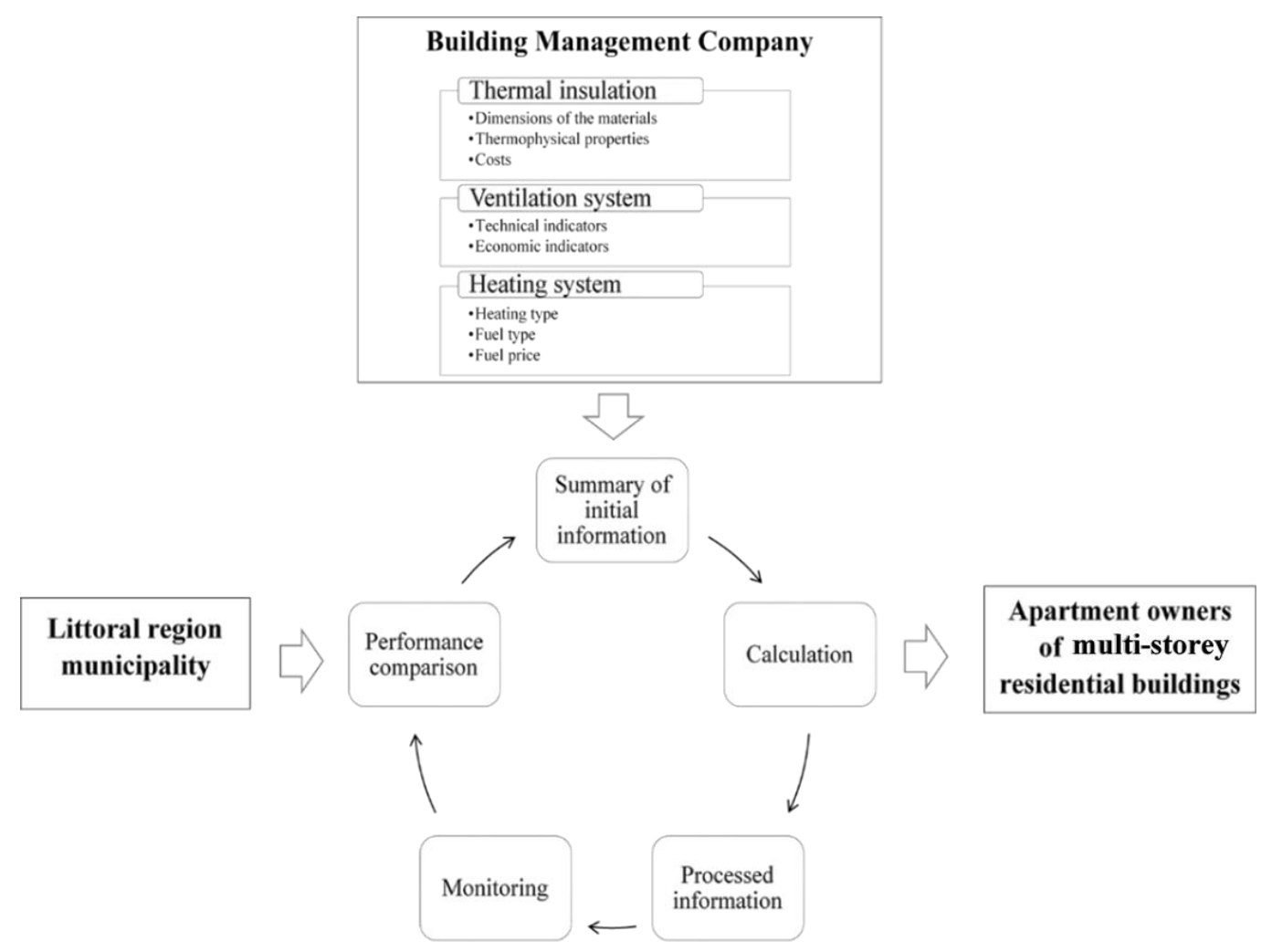

Fig. 4. The energy audit system in littoral regions (developed by the authors, based on Petrov, Puikevica-Puikevska \& Zeltinsh, 2002).

The research has demonstrated that most public and residential buildings in littoral regions of the Baltic Sea in Latvian do not have energy certification or recent energy audit. Justification of the current situation is related to limited financial resources of the apartment owners and tenants. The decision of the apartment owners to apply for the state or municipality co-financing to improve energy usage in a building determines the need for residential building energy audit and energy performance certificates.

\section{ENERGY PERFORMANCE CERTIFICATES OF PUBLIC AND RESIDENTIAL BUILDINGS IN LITTORAL REGIONS}

To compare the level of energy usage of a new or existing public or residential building, the standard measure used is house energy rating. Energy consumption in the chosen building is the main criterion of any international energy rating system, but there are also other significant factors that can be considered, such as environmental quality, thermal comfort, production of greenhouse gas emissions and cost efficiency.

The house energy rating tool is used all over the world. As the system in each country has been developed in different periods, there are many variations of building energy performance calculations (Zeltins, Actina, Zebergs, Vrublevskis \& Odineca, 2014). The following examples can be mentioned (Kordjamshidi, 2011): 
- the United States - house energy rating uses a 100-point scale of efficiency and it is further divided into 10 categories of star rating, which ranges from one star to five stars plus, developed in 1980;

- Australia - "5-Star" rating developed in 1980; "6-Star" rating since 2011; the minimum requirement in most buildings;

- Denmark - energy rating system since 1981;

- the United Kingdom - "National Home Energy Rating" system launched in 1991;

- Canada - "EnerGuide for houses", "EnerGuide for new houses", home energy ratings system since 1997 ;

- Brazil - "PROCEL EDIFICA" developed in 2003;

- France - "Diagnostic de performance energetique" developed in 2006, mandatory for all buildings registered after 1 July 2007;

- Ireland - "Building Energy Rating" system since 2007;

- China - national building energy rating and labelling system developed in 2008;

- Portugal - Energy Performance certification for new buildings launched in 2007, extended to existing buildings in 2009.

Practically all these systems involve a computer-model or a numerical description for the rating of the building against standard occupancy and activity templates (Vrubḷevskis, Zēbergs, Zeltiņš \& Puikevica-Puikevska, 2007). House energy rating system is required to encourage energy consumers to use the rating data in making housing purchase decision.

The house energy rating and energy performance certificates have been established in Latvia by the Law of Energy Efficiency for Buildings since 2013. The law stipulates the mandatory energy performance certification in the following cases:

- for a building to be designed, reconstructed or renovated in order to be put into service or sold;

- for a part of a building to be designed, reconstructed or renovated, to sell this part of the building, if it is provided with an individual energy metering;

- for an operating building for sale, lease or rent, if the customer requests energy certification;

- for a part of an operating building with a heated space of more than $50 \mathrm{~m}^{2}$ for sale, lease or rent, if the customer requests energy certification and if this part of the building has individual energy calculations or thermal energy accounting;

- for a public building owned by the state or a municipality with a heated area more than $250 \mathrm{~m}^{2}$;

- if the owner of the building has taken a decision on the energy certification of the building.

Considering the exceptions of the Directive 2012/27/EC, energy certification is not mandatory in the following cases:

- for buildings which do not use energy to regulate indoor microclimate; 
- for cultural monuments, if that undermines their cultural and historical value;

- for buildings designed and built for religious activities;

- for buildings designed and built for use only during the warm seasons (such as summer cottages);

- for buildings with a total heated area of less than $50 \mathrm{~m}^{2}$.

The possibility of evaluating a separate apartment is not excluded, but it can only be of practical significance if the apartment has its own autonomous heating system.

The energy performance benchmarking system of buildings comprises building energy performance indicators that characterize the comparison of heating consumption. "In the benchmarking scale, the following energy efficiency classes of buildings are used for residential buildings" (Zeltins, Actina, Zebergs, Vrublevskis \& Odineca, 2014):

- Class A - the energy efficiency indicator for heating does not exceed $40 \mathrm{kWh} / \mathrm{m}^{2}$ per year;

- Class B - the energy efficiency indicator for heating exceeds $40 \mathrm{kWh} / \mathrm{m}^{2}$ per year, but does not exceed $60 \mathrm{kWh} / \mathrm{m}^{2}$ per year;

- Class $\mathrm{C}$ - the energy efficiency indicator for heating exceeds $60 \mathrm{kWh} / \mathrm{m}^{2}$ per year, but does not exceed $80 \mathrm{kWh} / \mathrm{m}^{2}$ per year;

- Class D - the energy efficiency indicator for heating exceeds $80 \mathrm{kWh} / \mathrm{m}^{2}$ per year, but does not exceed $100 \mathrm{kWh} / \mathrm{m}^{2}$ per year;

- Class E - the energy efficiency indicator for heating exceeding $100 \mathrm{kWh} / \mathrm{m}^{2}$ per year, but not exceeding $150 \mathrm{kWh} / \mathrm{m}^{2}$ per year;

- Class F - the energy efficiency indicator for heating exceeds $150 \mathrm{kWh} / \mathrm{m}^{2}$ per year, the building needs energy efficiency improvement measures.

Minimum level of energy efficiency for heating of renewable multi-storey residential building does not exceed $90 \mathrm{kWh} / \mathrm{m}^{2}$ per year.

The latest research on energy consumption in multi-storey residential buildings has demonstrated that most of these buildings have local heat supply. The most widely used type of fuel is firewood.

\section{CONCLUSION}

The present research has shown that issues of energy and energy efficiency in public and residential buildings in littoral regions of Latvia are not dealt with at a proper level. The insufficiency of municipal authorities and eligible specialists impede the necessary data acquisition and processing to carried out the energy audit of public and residential buildings in littoral regions of the Baltic Sea successfully.

The main aim of the energy efficiency process management system in regions where the population is decreasing as is the case in littoral regions of the Baltic Sea in Latvia first of all should meeting the interests of residents and property owners.

To ensure the implementation of the chosen energy efficient solutions, it is recommended to use the energy efficient process management system in practice. 
Certification of residential and public buildings based on a classification according to heat consumption is still not regulated and implemented in Latvia, which impedes motivation for the implementation of energy efficient solutions.

\section{CONFLICT OF INTEREST}

Authors have personal and professional relationship with Editor-in-Chief of the journal. In this case, editorial process was carried out by Dr. Linda Kauškale, a Managing Editor of the Journal, who was invited to check the submission, recommend reviewers and make a final decision regarding the publication of this manuscript.

\section{REFERENCES}

Actina G., Zeltins N., \& Geipele I. (2014). Recommendations on implementation of governmental energy and energy efficiency policy planning and managing institutions at regional level in Latvia, Proceedings of WEC Central \& Eastern Europe regional energy forum (FOREN 2014), 22-26 June 2014, Palace of the Parliament, Bucharest, Romania, 201-211.

Actiņa, G., \& Geipele, S. (2016). Management of Energy Efficient Processes in Residential and Public Buildings at Regional Level: a Case Study of Latvia, Proceedings of the 2016 International Conference on Industrial Engineering and Operations Management, Malaysia, Kuala Lumpur, 810 March, Kuala Lumpur: IEOM Society, 1330-1338.

Akermanis A., Zebergs V., Zeltins N., Actina G., \& Odineca T. (2012). Situation with Heat Supply in Latvia: Current Problems and Search of Their Solution. FOREN2012: The Role of Governments, International Organizations and NGOs in addressing it. The Energy Trilemma. Overlook on Strategic Programs at European and Regional Level, Mesagerul energetics, Buletin informative al Comitetului National Roman al Consiliului Mondial al Energiei, ANUL XII, 131, 5-8.

Geipele, S., Geipele, I., Slava, D., \& Stāmure, I. (2012). Social, Economic and Legal Problems of Housing Management in Latvia. In: The 7th International Scientific Conference "Business and Management 2012”, Lithuania, Vilnius, 10-11 May, 2012, Vilnius Gediminas Technical University, 1-1. https://doi.org/10.3846/bm.2012.082

Hernandez, P., Burke, K., Lewis, \& Owen J. O. (2008). Development of energy performance benchmarks and building energy ratings for non-domestic buildings: An example for Irish primary schools, Energy and Building, 40(3), 249-254. https://doi.org/10.1016/j.enbuild.2007.02.020

Kordjamshidi, M. (2011). House rating schemes. GREEN, Springer. https://doi.org/10.1007/978-3$\underline{642-15790-5}$

Pelz, W. (2012). Strategisches und operatives marketing, ein leitfaden zur erstellung eines professionellen marketing-plans, Norderstedt 2004, (2. Auflage 2012 i.V.). (in German)

Petrov B., Puikevica-Puikevska I., \& Zeltinsh N. (2002). Program of energy audit for residential buildings, The Ninth International Conference on Indoor Air Quality and Climate "Indoor Air 2002" (CD), Monterey, California, USA, 6 p.

Saeima of the Republic of Latvia. (2010). Sustainable Development Strategy of Latvia until 2030, June 2010.

Sartori, I., \& Hestnes, A. G. (2007). Energy use in the life cycle of conventional and low-energy buildings: A review article, Energy and Buildings, 39(3), 249-257. https://doi.org/10.1016/j.enbuild.2006.07.001

Vrubḷlevskis, V., Zēbergs, N. Zeltiņš, I., \& Puikevica-Puikevska I. (2007). Additional energy saving in a building with improved insulation, Latvian Journal of Physics and Technical Sciences, 2, 32-40.

Zeltins N., Actina G., Zebergs V., Vrublevskis V., \& Odineca T. (2014). Impact of the thermal inertia of buildings upon the selection criteria of the energy efficiency measures, saved energy and its cost, Proceedings of 14th IAEE European Energy Conference Sustainable Energy Policy and Strategies for Europe, Rome, Italy, October 26-31, 2014, CD version. 


\section{AUTHORS' SHORT BIOGRAPHIES}

Baiba Pḷaviṇa, Mg. sc. ing., Researcher at Riga Technical University, Faculty of Engineering Economics and Management; PhD student at RTU. Baiba Pḷvina acquired higher education at the University of Latvia - Academic Master's degree in Social Sciences. Now she is the Head of Engure Parish of Engure Municipality and a member of the Guilds of Latvian House Managers. She participates in scientific conferences, research projects and develops her professional competences and skills.

ORCID iD: https://orcid.org/0000-0002-9434-8766

Gita Actina, Dr. oec, has been an Associate Professor at the Institute of Civil Engineering and Real Estate Economics of Riga Technical University since 2018. Since 2003, she has been the Head of the Latvian Energy Efficiency Network at the Institute of Physical Energetics of the Latvian Academy of Sciences. Since 2015, she has been a Researcher in the field of power industry. She participates in international and state-funded research projects on planning of sustainable development of the regional power sector. Gita Actina is a Doctor of Economics in the field of management science, subfield: public administration at Riga Technical University. The title of her Doctoral Thesis: "Development of Management System of Energy Efficient Processes in Latvia". Within over 10 years of professional experience, she has been participating in solution projects of energy economics problems at the Latvian National Committee of the World Energy Council. The findings of her studies are reflected in more than 30 publications, which have been presented at several national and international conferences.

ORCID iD: https://orcid.org/0000-0003-1603-6852 